\title{
Characteristics of the renal C-type natriuretic peptide receptor in hypertrophied and developing rat kidney
}

\author{
G E Woodard ${ }^{1}$, Xiaohong $\mathrm{Li}^{\mathbf{2}}$ and J A Rosado ${ }^{3}$ \\ ${ }^{1}$ National Institute of Diabetes and Digestive and Kidney Diseases, National Institutes of Health, Bethesda, Maryland 20892-1752, USA \\ ${ }^{2}$ Department of Medicine, Mount Sinai School of Medicine, New York, New York 10029, USA \\ ${ }^{3}$ Department of Physiology, University of Extremadura, Cáceres, Spain
}

(Requests for offprints should be addressed to G E Woodard; Email: GeoffreyW @ intra.niddk.nih.gov)

\begin{abstract}
This study investigates the effect of hypertrophy, using one kidney and one kidney/one clip rats, and development, comparing 3- and 12-week-old rats, on the expression of the 28-amino acid atrial natriuretic peptide $\left(\mathrm{ANP}_{1-28}\right)$ binding sites in rat kidney. Here we report an increased $B_{\max }$ value of glomerular binding sites for $A_{N P_{1-28}}$ and $C$-type natriuretic peptide 1-22 (CNP $\left.{ }_{1-22}\right)$ in hypertrophied and developing kidney, without modifying their affinity, an effect that was prevented in the presence of the synthetic des[Gln ${ }^{18}, \mathrm{Ser}^{19}$, Gly ${ }^{20}$, Leu $\left.{ }^{21}, \mathrm{Gly}^{22}\right] \mathrm{ANP}_{4-23^{-}}$-amide (C-ANF), suggesting that natriuretic peptide receptor (NPR)-C binding sites might be enhanced. The enhanced $B_{\max }$ was only detected in the high affinity binding site for $\mathrm{CNP}_{1-22}$, which has been identified as the $67 \mathrm{kDa}$ NPR-C-like protein. $\mathrm{A}$ similar effect was observed in renal glomeruli from 3-week-old rats compared with 12-week-old rats. Our results indicate that $\mathrm{ANP}_{1-28}, \mathrm{CNP}_{1-22}$ and $\mathrm{C}-\mathrm{ANF}$ inhibited $\mathrm{CAMP}$ synthesis stimulated by the physiological agonists histamine and 5-hydroxytryptamine or directly by forskolin. The inhibitory effect was found to be significantly greater in 1-kidney and 1-kidney/1-clip rats than in controls, and in 3-week-old rats compared with 12-week-old rats. Our observations suggest that this effect must be attributed to the $67 \mathrm{kDa}$ NPR-C-like protein due to the enhanced $\mathrm{B}_{\max }$ values and the reported inhibitory role for this receptor on adenylyl cyclase activity. The enhanced inhibitory role of natriuretic peptides on cAMP synthesis in hypertrophied and developing kidney may influence glomerular function in the rat kidney and suggests a role for the $67 \mathrm{kDa}$ NPR-C-like protein in growth.
\end{abstract}

Journal of Molecular Endocrinology (2005) 35, 519-530

\section{Introduction}

Natriuretic peptides are physiological messengers involved in the regulation of a number of cellular functions. The 28-amino acid atrial natriuretic peptide $\left(\mathrm{ANP}_{1-28}\right)$ is involved in the homeostasis of body fluids and the cardiovascular system (Rademaker \& Richards 2005). On the other hand, the function of other natriuretic peptides, such as brain, C-type or dendroaspis natriuretic peptides (BNP, GNP and DNP) is associated with renal and vascular homeostasis (Matsuo 2001, Dhinga et al. 2002, Woodard et al. 2002, Scotland et al. 2005). GNP has also been presented as a local modulator with antiproliferative effects in the vascular cell system (Matsuo 2001). The effects of these natriuretic peptides are mediated by three types of natriuretic peptide receptors (NPR), NPR-A, -B and -C (Nakao et al. 1992). NPR-A and NPR-B, of approximately $120 \mathrm{kDa}$, have agonist-dependent guanylate cyclase domains (Anand-Srivastava 1997, Woodard et al. 2004b, Fan et al. 2005). NPR-A is activated with high affinities by $\mathrm{ANP}_{1-28}$ and $\mathrm{BNP}$, but hardly binds $\mathrm{CNP}_{1-22}$, which is known to be an agonist of NPR-B
(Koller et al. 1991). The third NPR, NPR-C, is a disulphide-bridged homodimer of 67 and $77 \mathrm{kDa}$ units with a broad range of ligands, including $\mathrm{ANP}_{1-28}, \mathrm{BNP}$, GNP and the synthetic des $\left[\mathrm{Gln}^{18}\right.$, Ser ${ }^{19}, \mathrm{Gly}^{20}, \mathrm{Leu}^{21}$, $\left.\mathrm{Gly}^{22}\right] \mathrm{ANP}_{4-23}$-amide (C-ANF) (Koller et al. 1991), which shows no affinity for NPR-A or NPR-B (Koller et al. 1991, Brown \& Chen 1995). The $77 \mathrm{kDa}$ protein is involved in ligand internalization as a clearance receptor (Chen \& Bennet 1998) and has a low affinity for $\mathrm{CNP}_{1-22}$, while the $67 \mathrm{kDa}$ protein shows a high affinity for $\mathrm{CNP}_{1-22}$ and is involved in the regulation of fluid homeostasis by regulating cAMP synthesis (Anand-Srivastava \& Trachte 1993, Woodard et al. 2004a).

A number of physiological effects mediated by $\mathrm{ANP}_{1-28}$, such as the modulation of adrenergic neurotransmission, are associated with a reduction in the production of cAMP rather than with stimulation of cGMP synthesis. These effects are shared by the truncated analogue $\mathrm{C}-\mathrm{ANF}$, which, as well as $\mathrm{ANP}_{1-28}$, inhibits the activity of adenylyl cyclase in some membrane preparations by a mechanism sensitive to guanosine trisphosphate (GTP) and pertussis toxin (Anand-Srivastava \& Trachte 1993). 
A number of studies have reported that natriuretic peptides exert growth regulatory properties, and NPR-C has been presented as a candidate to mediate this function. Natriuretic peptides caused antimitogenic and antiproliferative effects in cultured glomerular mesangial cells in kidney (Appel 1990). Natriuretic peptides also showed growth-regulatory properties in a variety of other tissues and cells, such as brain, bone, myocytes, lung, red blood cell precursors and endothelial cells (Appel 1992, Lu et al. 2004, Murakami et al. 2004). Although initial data indicated that the antigrowth properties of natriuretic peptides correlated with the ability to generate cGMP (Appel 1990), it was shown that occupation of NPR-C by C-ANF blocks the antimitogenic effect of $\mathrm{ANP}_{1-28}$ on rat aortic smooth muscle cells (Cahill \& Hassid 1994). In addition, it has been shown that $\mathrm{ANP}_{1-28}$ and $\mathrm{C}-\mathrm{ANF}$ exert equipotent inhibitory effects of astrocyte proliferation, which suggests that NPR-G might account for these actions (Prins et al. 1996).

In the present study, we have investigated the possible relationship between the NPR-C-like proteins and tissue growth using experimental models of 'one-kidney' (1K) and 'one-kidney/one-clip' $(1 \mathrm{~K} / 1 \mathrm{C})$ rats, which induce kidney hypertrophy. In addition, we have performed the study in 3-week-old rats that are in a growth state. We have found that in hypertrophied and developing kidneys there is an increased glomerular expression of the $67 \mathrm{kDa}$ NPR-C-like receptor. Consistent with this, we have observed that the ability of natriuretic peptides to inhibit agonist-induced cAMP production is increased under these conditions, which further supports the enhanced expression of the $67 \mathrm{kDa}$ NPR-C-like protein and suggests a role for this receptor in the regulation of growth.

\section{Materials and methods}

\section{Materials}

${ }^{125}$ I-Labelled $\quad \mathrm{ANP}_{1-28}, \quad{ }^{125}$ I-labelled $\quad \mathrm{CNP}_{1-22},{ }^{125} \mathrm{I}$ standard, Hyperfilm ${ }^{3} \mathrm{H}$ for autoradiography, and cAMP radioimmunoassay commercial kits were from Amersham Biosciences, UK. $\mathrm{ANP}_{1-28}, \mathrm{CNP}_{1-22}$ and C-ANF were from Peninsula Laboratories (Merseyside, UK). Isobutylmethylxanthine (IBMX), histamine, 5-hydroxytryptamine (5-HT), forskolin, sodium dodecyl sulphate (SDS), bovine serum albumin (BSA), bromophenol blue, bicinchoninic acid protein assay reagent (BCA) and Tris were from Sigma (Poole, Dorset, UK). All other reagents were of analytical grade.

\section{Animals}

Rats were from Charles River (Margate, Kent, UK). Eighteen male Wistar-Kyoto rats (250-350 g, Charles
River Breeding) were separated into three equal groups: a control group, a one kidney group $(1 \mathrm{~K})$ and a one kidney/one clip group $(1 \mathrm{~K} / 1 \mathrm{C})$. All procedures were approved by the Local Ethical Committee. $1 \mathrm{~K} / 1 \mathrm{C}$ rats were produced by partial constriction of the left renal artery with ligation and removal of the contralateral kidney under sodium pentobarbital anaesthesia (60 mg/kg intraperitoneally). $1 \mathrm{~K}$ rats were subjected to right nephrectomy. Control rats were subjected to sham operation. All rats were maintained for 6 weeks on regular rat chow, pair-fed, and tap water was available ad libitum. Systolic blood pressure was measured indirectly by tail-cuff plethysmography (I.I.T.C., Life Science, USA), with the tail maintained at $37^{\circ} \mathrm{C}$. Six weeks after surgery, 18 rats from the $1 \mathrm{~K}, 1 \mathrm{~K} / 1 \mathrm{G}$ and control groups were killed by decapitation. Kidneys were rapidly removed, placed in ice-cold Hank's balanced salt solution (HBSS), containing (in $\mathrm{mM}$ ): $137 \mathrm{NaCl}, 10$ HEPES, $5.4 \mathrm{KCl}, 0.4 \mathrm{Mg}_{2} \mathrm{SO}_{4}, 0.34 \mathrm{Na}_{2} \mathrm{HPO}_{4}, 1.26$ $\mathrm{CaCl}_{2}, 4.17 \mathrm{Na}_{2} \mathrm{HCO}_{3}, 0.44 \mathrm{~K}_{2} \mathrm{HPO}_{4}, 0.49 \mathrm{MgCl}_{2}$, $0 \cdot 2 \%(\mathrm{w} / \mathrm{v}) \mathrm{BSA}$ and $5 \cdot 56$ glucose, $\mathrm{pH} 7 \cdot 2$, and weighed after death. Body weight was recorded immediately before decapitation.

Eighteen male 12-week-old Wistar-Kyoto rats (350$400 \mathrm{~g}$ ) and eighteen male 3-week-old Wistar-Kyoto rats (81-92 g), maintained in an environment with constant humidity and temperature with free access to food and water, were killed by decapitation. Kidneys were rapidly removed, placed in HBSS and weighed after death. Body weight was recorded immediately before decapitation as described above.

\section{Competitive inhibition of ${ }^{125} \mid-A_{N P}{ }_{1-28}$ or ${ }^{125} \mid-C_{N P}{ }_{1-22}$ binding}

Consecutive $15 \mu \mathrm{m}$ transverse sections through the level of the renal papilla from the kidneys of six rats in each group were suspended in PBS (containing in $\mathrm{mM}$ ): 120 $\mathrm{NaCl}, 21.6 \quad \mathrm{Na}_{2} \mathrm{HPO}_{4}, 8 \cdot 4 \mathrm{NaH}_{2} \mathrm{PO}_{4}, \mathrm{pH} 7 \cdot 2$, and supplemented with $1 \mathrm{mM} \mathrm{1,10-phenanthroline,} \mathrm{a} \mathrm{metal-}$ loproteinase inhibitor, which has been shown to inhibit the degradation of natriuretic peptides (Johnson \& Foster 1990). Under our experimental conditions, HPLC studies have suggested that ${ }^{125}{\mathrm{I}-\mathrm{ANP}_{1-28}}_{1}$ has a similar recovery pattern after incubation with renal sections from $1 \mathrm{~K}, 1 \mathrm{~K} / 1 \mathrm{C}$ and control rats $(64 \cdot 7 \pm 7 \cdot 1$, $66 \cdot 9 \pm 6 \cdot 8$ and $65 \cdot 9 \pm 6 \cdot 4, \quad P>0 \cdot 05)$ as well as from 3 -week-old rats and 12-week-old rats $(69 \cdot 1 \pm 8 \cdot 5$ and $67 \cdot 8 \pm 6 \cdot 9, P>0 \cdot 05)$. This suggests that the effective concentrations of the radioligand were similar during incubations among renal sections from different group of rats.

Kidney slides were incubated with $100 \mathrm{pM}$ ${ }^{125} \mathrm{I}-\mathrm{ANP}_{1-28}$ or ${ }^{125} \mathrm{I}_{-\mathrm{CNP}} \mathrm{C}_{1-22}(2000 \mathrm{Ci} / \mathrm{mmol})$ in the absence or presence of various concentrations $(1 \mathrm{pM}$ to $1 \mu \mathrm{M})$ of unlabelled rat $\mathrm{ANP}_{1-28}, \mathrm{CNP}_{1-22}$, or $\mathrm{C}$-ANF 
Table 1 Systolic blood pressure, heart weight, kidney weight and glomerular protein content of control, 1 -kidney $(1 \mathrm{~K})$, and 1-kidney, 1 -clip $(1 \mathrm{~K} / 1 \mathrm{C})$ rats. Values are means \pm S.E.M.

\begin{tabular}{|c|c|c|c|}
\hline & Control & $1 \mathrm{~K}$ rats & $1 \mathrm{~K} / 1 \mathrm{C}$ rats \\
\hline \multicolumn{4}{|l|}{ Variable } \\
\hline Blood pressure (mm Hg) & $113 \pm 8 \cdot 7$ & $121 \pm 9 \cdot 8$ & $152 \pm 7 \cdot 8^{*}$ \\
\hline Body weight $(\mathrm{g})$ & $316 \pm 11 \cdot 2$ & $309 \pm 9 \cdot 1$ & $301 \pm 8 \cdot 7$ \\
\hline Kidney weight (g) & $0.93 \pm 0.04 \dagger$ & $1 \cdot 34 \pm 0.07^{*}$ & $1.29 \pm 0.06$ \\
\hline Heart weight $(\mathrm{g})$ & $1.03 \pm 0.07$ & $1 \cdot 09 \pm 0 \cdot 10$ & $1 \cdot 19 \pm 0 \cdot 12$ \\
\hline Protein content $(\mu \mathrm{g} / \mathrm{glomeruli})$ & $0.58 \pm 0.05$ & $0.60 \pm 0.07$ & $0.61 \pm 0.09$ \\
\hline
\end{tabular}

for $15 \mathrm{~min}$ at $20^{\circ} \mathrm{C}$ as described previously (Woodard et al. 2005). After incubation, the sections were exposed to Hyperfilm ${ }^{3} \mathrm{H}$ for 31 days.

Protein content in tissue sections was determined by the Lowry protein assay. The values were used to convert $\mathrm{B}_{\max }$ values from $\mathrm{fmol} / \mathrm{mm}^{2}$ to $\mathrm{fmol} / \mathrm{mg}$ protein. Briefly, tissue blocks were washed and the cell suspension was then sonicated (Ultrasonics Inc. Model $\mathrm{W}-220 \mathrm{~F})$ in $1 \mathrm{ml} 0.9 \% \mathrm{NaCl}$. Sample solution $(50 \mu \mathrm{l})$ or protein standard $(50 \mu \mathrm{l}$; range from $0-250 \mu \mathrm{g}$ protein/ $\mathrm{ml}$ ) was incubated with $1 \mathrm{ml}$ BCA for $30 \mathrm{~min}$ at $60{ }^{\circ} \mathrm{C}$. After incubation, the samples were read at $562 \mathrm{~nm}$ with a spectrophotometer (PU 8600 uv/vis, PYE UNICAM Ltd, UK). The linear relationship between the absorption at $562 \mathrm{~nm}$ and protein content was established for protein standards and this was used to obtain the protein content of unknown samples.

\section{cAMP accumulation in renal glomeruli}

Isolation of rat glomeruli was performed as described previously (Woodard et al. 2004a). Briefly, kidneys were removed and placed in ice-cold HBSS, containing (in $\mathrm{mM}$ ): $137 \mathrm{NaCl}, 10$ HEPES, $5.4 \mathrm{KCl}, 0.4 \mathrm{Mg}_{2} \mathrm{SO}_{4}$, $0.34 \quad \mathrm{Na}_{2} \mathrm{HPO}_{4}, \quad 1.26 \mathrm{CaCl}_{2}, 4 \cdot 17 \quad \mathrm{Na}_{2} \mathrm{HCO}_{3}, 0 \cdot 44$ $\mathrm{K}_{2} \mathrm{HPO}_{4}, 0 \cdot 49 \quad \mathrm{MgCl}_{2}, 0 \cdot 2 \%(\mathrm{w} / \mathrm{v})$ BSA and $5 \cdot 56$ glucose, $\mathrm{pH} 7 \cdot 2$. The cortices were minced and glomeruli were isolated by differential sieving. Aliquots of 100 glomeruli $(7.6 \mathrm{mg}$ protein) were suspended in HBSS plus $0 \cdot 2 \%$ BSA with $1 \mathrm{mM}$ IBMX and then incubated for $10 \mathrm{~min}$ at $20^{\circ} \mathrm{C}$ with different agonists in the absence or presence of natriuretic peptides as indicated. Incubations were terminated by ice-cold trichloroacetic acid as previously described (Brown \& Zuo 1992, 1994). Aliquots were then centrifuged at $4000 \boldsymbol{g}$ for $10 \mathrm{~min}$, and the supernatants were extracted with ether and radioimmunoassayed for cAMP as previously described (Brown \& Zuo 1992, 1994).

\section{Data analysis}

The data on blood pressure, body weight and kidney weight are presented as means \pm S.E.M. Data were analysed using the LIGAND program. Analysis of statistical significance was performed using the Student's $t$-test. The significance level was $P<0 \cdot 05$.

\section{Results}

\section{Competitive inhibition of ${ }^{125} \mathrm{I}_{-\mathrm{ANP}_{1-28}}$ binding in hypertrophied rat kidneys}

In order to investigate the properties of NPR in hypertrophied kidneys, we used the $1 \mathrm{~K}$ and the $1 \mathrm{~K} / 1 \mathrm{C}$ rat models. Table 1 summarizes the systolic blood pressure, heart weight, kidney weight and glomerular protein content of $1 \mathrm{~K}, 1 \mathrm{~K} / 1 \mathrm{C}$ and control rats. As shown in Table 1 , the kidney weight of both $1 \mathrm{~K}$ and $1 \mathrm{~K} / 1 \mathrm{C}$ rats is increased in comparison with that of control rats $(P<0.05)$. In addition, blood pressure in $1 \mathrm{~K} / 1 \mathrm{C}$ rats is significantly elevated compared with control rats $(P<0 \cdot 01)$.

As shown in Fig. 1, autoradiographs revealed specifically reversible binding of $100 \mathrm{pM}{ }^{125} \mathrm{I}_{-\mathrm{ANP}_{1-28}}$ mainly to glomeruli of control, $1 \mathrm{~K}$ and $1 \mathrm{~K} / 1 \mathrm{C}$ rats. The competitive inhibition of ${ }^{125} \mathrm{I}_{-} \mathrm{ANP}_{1-28}$ by unlabelled $\mathrm{ANP}_{1-28}$ on glomeruli of control, $1 \mathrm{~K}$ and $1 \mathrm{~K} / 1 \mathrm{C}$ rats was consistent with reversible binding sites for $\mathrm{ANP}_{1-28}$. The $\mathrm{pKa}$ values are not significantly different among the three groups of rats, but the $B_{\max }$ values from $1 \mathrm{~K}$ and $1 \mathrm{~K} / 1 \mathrm{C}$ rats are significantly higher than those from the control rats (Table 2; $P<0 \cdot 01$ ), which indicated that receptor binding to $\mathrm{ANP}_{1-28}$ is significantly increased in the glomeruli of both $1 \mathrm{~K}$ and $1 \mathrm{~K} / 1 \mathrm{C}$ rats. $\mathrm{ANP}_{1-28}$ binding to the papilla is not significantly different among these three group of rats $(P>0 \cdot 05)$. The $\mathrm{pKa}$ and $\mathrm{B}_{\max }$ were, respectively, $8 \cdot 31 \pm 1.3$ and $729 \pm 89 \mathrm{fmol} / \mathrm{mg}$ protein for control rats, $8 \cdot 46 \pm 1 \cdot 7$ and $819 \pm$ $91 \mathrm{fmol} / \mathrm{mg}$ protein for $1 \mathrm{~K}$ rats and $8 \cdot 18 \pm 1 \cdot 4$ and $799 \pm 83 \mathrm{fmol} / \mathrm{mg}$ protein for $1 \mathrm{~K} / 1 \mathrm{C}$ rats $(n=6)$. The papilla expresses NPR-A but not detectable NPR-G-like binding sites in the rat (Brown \& Zuo 1992). Consistent with this, $1 \mu \mathrm{M}$ C-ANF did not significantly alter the specific binding of $100 \mathrm{pM}^{125}{\mathrm{I}-\mathrm{ANP}_{1-28}}_{10}$ the papilla in control rats $(91 \cdot 1 \pm 7 \cdot 7 \%$ of control), $1 \mathrm{~K}$ rats $(89 \cdot 1$ $\pm 9 \cdot 7 \%$ of control) or $1 \mathrm{~K} / 1 \mathrm{C}$ rats $(91 \cdot 3 \pm 9 \cdot 1 \%$ of 


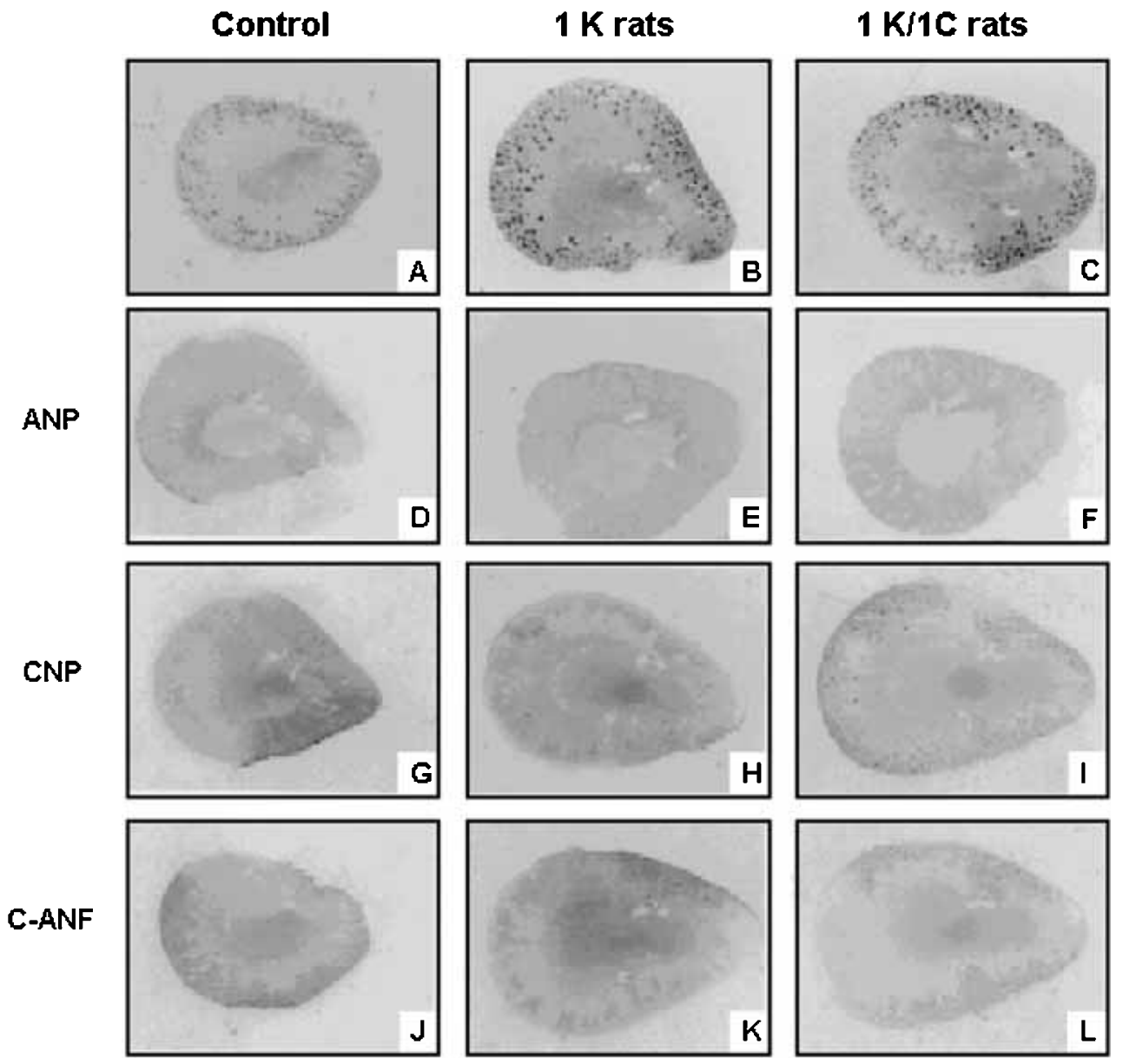

Figure 1 Autoradiographs of renal binding of $100 \mathrm{pM}^{125} \mathrm{I}_{-\mathrm{ANP}_{1-28}}$ in rats. Sections of kidney from control, $1 \mathrm{~K}$ rats and $1 \mathrm{~K} / 1 \mathrm{C}$ rats were incubated with $100 \mathrm{pM}{ }^{125} \mathrm{I}-\mathrm{ANP}{ }_{1-28}$ in the absence $(\mathrm{A}, \mathrm{B}$ and $\mathrm{C})$ and presence of $1 \mu \mathrm{M} \mathrm{ANP}_{1-28}(\mathrm{D}, \mathrm{E}$ and $\mathrm{F}), \mathrm{CNP}_{1-22}(\mathrm{G}, \mathrm{H}$ and $\mathrm{I})$ and $\mathrm{C}-\mathrm{ANF}(\mathrm{J}, \mathrm{K}$ and $\mathrm{L})$ at $20^{\circ} \mathrm{C}$ for $15 \mathrm{~min}$. Autoradiography was performed as described under Materials and methods. The autoradiograms are representative of six separate determinations.

Table 2 Binding constants for the specifically reversible binding of $\mathrm{ANP}_{1-28}$ or $\mathrm{CNP}_{1-22}$ in the glomeruli of control, 1 kidney (1K), and 1 kidney, 1 clip $(1 \mathrm{~K} / 1 \mathrm{C})$ rats. Values are means \pm S.E.M.

\section{Control rats}

\begin{tabular}{|c|c|c|c|}
\hline & pKa & $\begin{array}{l}K_{\mathrm{d}} \\
(\mathrm{nM})\end{array}$ & $\begin{array}{l}\mathrm{B}_{\max } \\
\text { (fmol/mg protein) }\end{array}$ \\
\hline \multicolumn{4}{|l|}{ Ligand } \\
\hline $\mathrm{HA}+\mathrm{A}$ & $8 \cdot 39 \pm 1 \cdot 01$ & $4 \cdot 16$ & $555 \pm 78$ \\
\hline \multirow[t]{2}{*}{$\mathrm{HA}+\mathrm{C}$} & $8.52 \pm 0.33$ & 2.44 & $358 \pm 14$ \\
\hline & $5.62 \pm 0.90$ & 3.48 & $138 \pm 11$ \\
\hline $\mathrm{HC}+\mathrm{C}$ & $8 \cdot 31 \pm 1 \cdot 20$ & 4.97 & $226 \pm 33$ \\
\hline $\mathrm{HC}+\mathrm{A}$ & $8.07 \pm 0.73$ & 8.52 & $267 \pm 9 \cdot 1$ \\
\hline
\end{tabular}

\section{$1 \mathrm{~K}$ rats}

\begin{tabular}{|c|c|c|}
\hline pKa & $\begin{array}{l}K_{\mathrm{d}} \\
(\mathrm{nM})\end{array}$ & $\begin{array}{l}\mathrm{B}_{\max } \\
\text { (fmol/mg protein) }\end{array}$ \\
\hline $8 \cdot 52 \pm 0 \cdot 81$ & 3.00 & $929 \pm 84^{\star *}$ \\
\hline $8.55 \pm 0.94$ & $2 \cdot 44$ & $853 \pm 37^{\star \star}$ \\
\hline $3 \cdot 82 \pm 1 \cdot 21$ & 2.82 & $141 \pm 7$ \\
\hline $8 \cdot 26 \pm 1 \cdot 00$ & 5.50 & $783 \pm 97^{* *}$ \\
\hline $8.25 \pm 0.73$ & 5.58 & $765 \pm 35^{\star *}$ \\
\hline
\end{tabular}

$1 \mathrm{~K} / 1 \mathrm{C}$ rats

\begin{tabular}{|c|c|c|}
\hline pKa & $\begin{array}{l}K_{\mathrm{d}} \\
(\mathrm{nM})\end{array}$ & $\begin{array}{l}\mathrm{B}_{\max } \\
\text { (fmol/mg protein) }\end{array}$ \\
\hline $8 \cdot 43 \pm 1 \cdot 30$ & $3 \cdot 78$ & $902 \pm 38^{* *}$ \\
\hline $8.46 \pm 0.85$ & 2.44 & $669 \pm 14^{* *}$ \\
\hline $3 \cdot 42 \pm 1 \cdot 21$ & 3.91 & $144 \pm 7$ \\
\hline $8 \cdot 14 \pm 0.83$ & $7 \cdot 32$ & $685 \pm 79^{* *}$ \\
\hline $8 \cdot 25 \pm 1 \cdot 20$ & 5.56 & $771 \pm 49^{\star *}$ \\
\hline
\end{tabular}

The maximum binding capacities $\left(\mathrm{B}_{\text {max }}\right)$ and pKa were assessed from the competitive inhibition of the binding of $100 \mathrm{pM} 125 \mathrm{I}-\mathrm{ANP}{ }_{1-28}$ and $200 \mathrm{pM}$ ${ }^{125} \mathrm{I}_{-} \mathrm{CNP}_{1-22}$ by various concentrations of unlabelled $\mathrm{ANP}_{1-28}$ or $\mathrm{CNP}_{1-22}$. Apparent dissociation constants $\left(K_{\mathrm{d}}\right)$ are also given. ${ }^{\star \star} P<0.01$ relative to control rats. $\mathrm{HA},{ }^{125} \mathrm{I}-\mathrm{ANP}_{1-28} ; \mathrm{A}, \mathrm{ANP}_{1-28} ; \mathrm{HC},{ }^{125} \mathrm{I}-\mathrm{CNP}_{1-22} ; \mathrm{C}, \mathrm{CNP}_{1-22}$. In $\mathrm{HA}+\mathrm{C}$ data for high and low affinity binding sites are reported. 


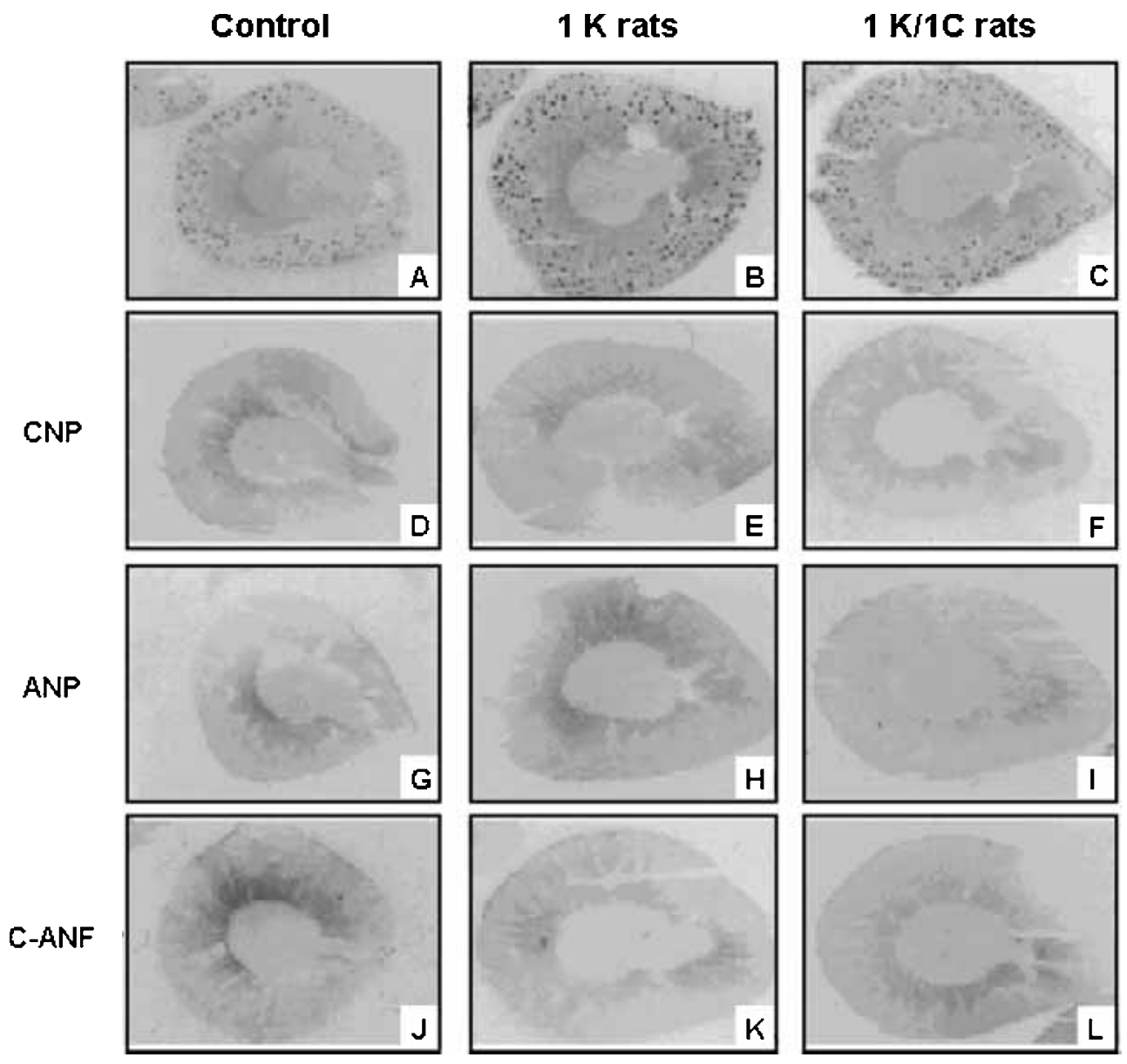

Figure 2 Autoradiographs of renal binding of $100 \mathrm{pM}{ }^{125}-\mathrm{CNP}_{1-22}$ in rats. Sections of kidney from control, $1 \mathrm{~K}$ rats and $1 \mathrm{~K} / 1 \mathrm{C}$ rats were incubated with $100 \mathrm{pM}{ }^{125} \mathrm{I}-\mathrm{CNP} \mathrm{P}_{1-22}$ in the absence $(\mathrm{A}, \mathrm{B}$ and $\mathrm{C})$ and presence of $1 \mu \mathrm{M} \mathrm{CNP}_{1-22}(\mathrm{D}, \mathrm{E}$ and $\mathrm{F}), \mathrm{ANP}_{1-28}(\mathrm{G}, \mathrm{H}$ and $\mathrm{I})$ and $\mathrm{C}-\mathrm{ANF}(\mathrm{J}, \mathrm{K}$ and $\mathrm{L})$ at $20^{\circ} \mathrm{C}$ for $15 \mathrm{~min}$. Autoradiography was performed as described under Materials and methods. The autoradiograms are representative of six separate determinations.

control). On the other hand, in renal glomeruli the competitive inhibition of ${ }^{125} \mathrm{I}_{-} \mathrm{ANP}_{1-28}$ by unlabelled C-ANF showed that $1 \mu \mathrm{M}$ C-ANF abolished the difference of $\mathrm{ANP}_{1-28}$ binding among the three groups. Thus, the $\mathrm{B}_{\max }$ values for specific glomerular binding of ${ }^{125} \mathrm{I}_{-} \mathrm{ANP}_{1-28}$ in the presence of C-ANF were $159 \cdot 6 \pm$ $12 \cdot 3,169 \cdot 6 \pm 21 \cdot 3$ and $157 \cdot 6 \pm 18 \cdot 1 \mathrm{fmol} / \mathrm{mg}$ protein in control, $1 \mathrm{~K}$ and $1 \mathrm{~K} / 1 \mathrm{C}$ rats $(P>0 \cdot 05)$. This suggests that the expression of the NPR-C-like binding sites on glomeruli increases in $1 \mathrm{~K}$ and $1 \mathrm{~K} / 1 \mathrm{C}$ rats, but NPR-A remains unaltered in these two groups compared with controls.

The competitive inhibition of ${ }^{125} \mathrm{I}_{-} \mathrm{ANP}_{1-28}$ binding to renal glomeruli by $\mathrm{CNP}_{1-22}$ confirmed this conclusion by showing two binding sites with different affinities for $\mathrm{CNP}_{1-22}$ in control, $1 \mathrm{~K}$ and $1 \mathrm{~K} / 1 \mathrm{C}$ rats. The $\mathrm{pKa}$ and $\mathrm{B}_{\max }$ values for these two binding sites are shown in Table 2. Our results indicate that the binding site with high affinity for $\mathrm{CNP}_{1-22}$, which resembles the $67 \mathrm{kDa}$ protein, was significantly increased in the glomeruli of both $1 \mathrm{~K}$ and $1 \mathrm{~K} / 1 \mathrm{C}$ rats compared with controls $(P<0 \cdot 01)$; however the binding site with low affinity for $\mathrm{CNP}_{1-22}$, which resembles the $77 \mathrm{kDa}$ protein, is not altered in $1 \mathrm{~K} / 1 \mathrm{C}$ rats $(P>0 \cdot 05)$.

\section{Competitive inhibition of ${ }^{125}$ - $^{-C N P_{1-22}}$ binding in hypertrophied rat kidneys}

As shown in Fig. 2, autoradiographs revealed that $100 \mathrm{pM}{ }^{125} \mathrm{I}_{-\mathrm{CNP}_{1-22}}$ binds to glomeruli of the three groups of rats. The binding was restricted to glomeruli in the three experimental groups and was reversibly inhibited by increasing concentrations of unlabelled $\mathrm{CNP}_{1-22}$. This inhibition was consistent with glomerular binding sites of uniform affinity for this ligand. The $\mathrm{pKa}$ and $\mathrm{B}_{\max }$ values for the glomerular site among the three groups of rats are shown in Table 2. The pKa values were 

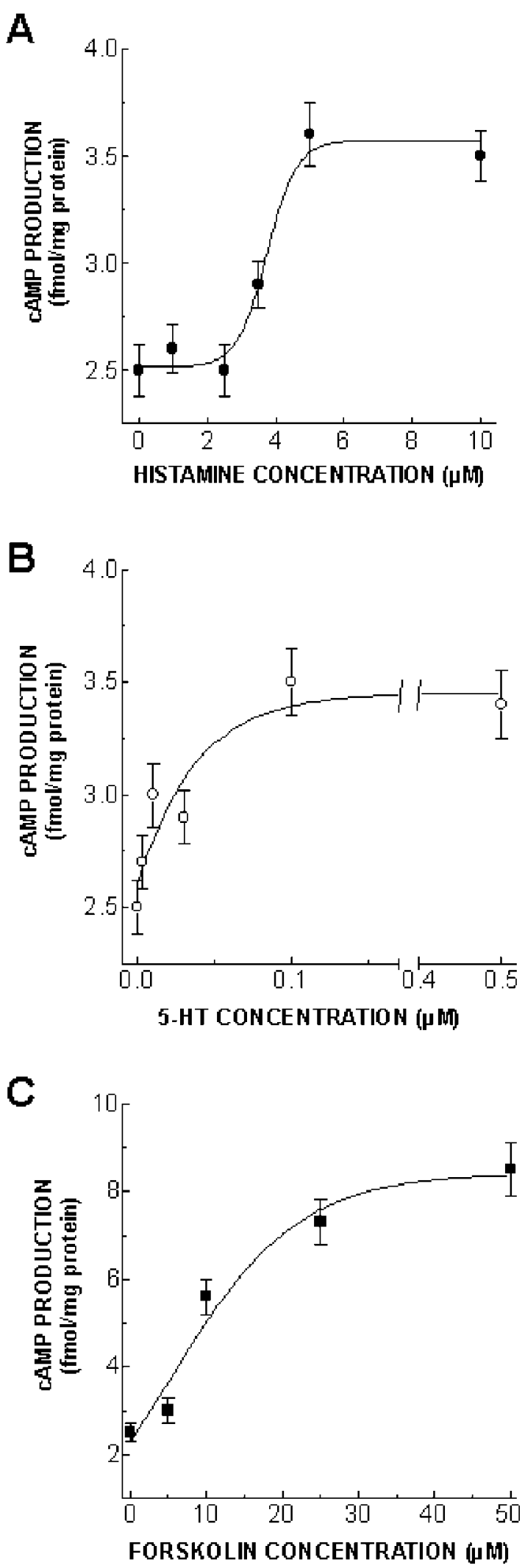

Journal of Molecular Endocrinology (2005) 35, 519-530 not significantly different $(P>0 \cdot 05)$, which suggests that the characteristic ligand affinities of these NPR-C-like sites have no significant difference among the three groups of rats. However, the $\mathrm{B}_{\max }$ values indicated that this class of binding was significantly increased in $1 \mathrm{~K}$ and $1 \mathrm{~K} / 1 \mathrm{C}$ rats compared with the control group $(P<0 \cdot 01)$. Further competitive inhibition of ${ }^{125} \mathrm{I}_{-\mathrm{CNP}_{1-22}}$ binding to glomeruli by $\mathrm{ANP}_{1-28}$ revealed that this class in each group had high affinity for $\mathrm{CNP}_{1-22}$ and $\mathrm{ANP}_{1-28}$ (Table 2 ). The increase in glomerular $B_{\max }$ for natriuretic peptides found with ${ }^{125} \mathrm{I}_{-\mathrm{CNP}} \mathrm{CN}_{1-22}$ was similar to the increase in glomerular $\mathrm{B}_{\max }$ for $\mathrm{ANP}_{1-28}$ discovered with ${ }^{125} \mathrm{I}$ $\mathrm{ANP}_{1-28}$ as well as to the increase in $\mathrm{B}_{\text {max }}$ for the class of glomerular sites with high affinity for $\mathrm{CNP}_{1-22}$ revealed by ${ }^{125} \mathrm{I}-\mathrm{ANP}_{1-28}$. All the binding data, therefore, support the idea that kidney hypertrophy in $1 \mathrm{~K}$ and $1 \mathrm{~K} / 1 \mathrm{C}$ rats significantly increases the expression of the high affinity NPR-C-like protein binding site without changing its affinity to the ligand or altering sites related to NPR-A or to the low affinity NPR-C-like protein.

\section{Effects of $\mathrm{ANP}_{1-28}, \mathrm{CNP}_{1-22}$ or C-ANF on cAMP stimulated by histamine, 5-hydroxytryptamine or forskolin}

The basal rate of glomerular cAMP accumulation in the presence of IBMX was $2 \cdot 5 \pm 0 \cdot 3,2 \cdot 0 \pm 0 \cdot 3$ and $2 \cdot 1 \pm$ $0.4 \mathrm{fmol} / \mathrm{mg}$ protein in control, $1 \mathrm{~K}$ and $1 \mathrm{~K} / 1 \mathrm{C}$ rats respectively. Treatment of renal glomeruli from control rats with the physiological agonists histamine and 5-hydroxytryptamine (5-HT) or with forskolin significantly increased the glomerular cAMP production in control rats in a concentration dependent manner (Fig. 3; $n=6)$. We have found that treatment of renal glomeruli with $\mathrm{ANP}_{1-28}, \mathrm{CNP}_{1-22}$ and $\mathrm{C}$-ANF reduced cAMP production stimulated by $5 \mu \mathrm{M}$ histamine, $0 \cdot 1 \mu \mathrm{M} 5$-HT and $10 \mu \mathrm{M}$ forskolin (Fig. 4; $n=6$ ). These effects were significantly greater in glomeruli from $1 \mathrm{~K}$ and in most cases was also greater in $1 \mathrm{~K} / 1 \mathrm{C}$ rats (Fig. 4; $P<0 \cdot 05$ ). These findings suggest that kidney hypertrophy increases the glomerular expression of the $67 \mathrm{kDa}$ NPR-C-like protein.

\section{Competitive inhibition of ${ }^{125} \mathrm{I}_{-\mathrm{ANP}_{1-28}}$ and ${ }_{125} \mathrm{I}_{-\mathrm{CNP}_{1-22}}$ binding in 3- and 12-week-old rats}

Comparison of autoradiography with the corresponding stained tissue sections revealed a specific reversible

Figure 3 Concentration-dependent cAMP generation by agonists in glomeruli from control rats. Glomeruli from control rats were stimulated with increasing concentrations of histamine (1-10 $\mu \mathrm{M} ; \mathrm{A})$, 5-hydroxytryptamine (5-HT; $0.01-0.5 \mu \mathrm{M}$; B) or forskolin (5-50 $\mu \mathrm{M}$; C). cAMP synthesis was measured as described under Materials and methods; values are expressed as $\mathrm{fmol} / \mathrm{mg}$ protein and are presented as means \pm S.E.M. from six separate experiments. 
A

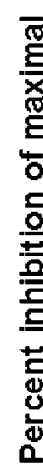

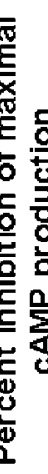

\section{ANP $_{1-28}$}

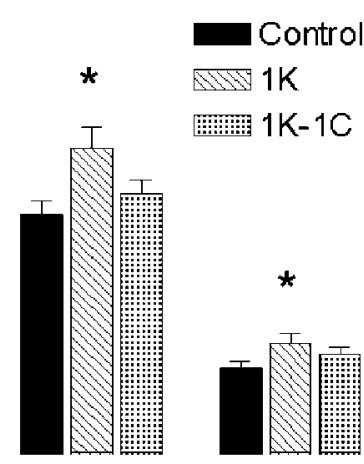

5-HT FORSKOLIN
B

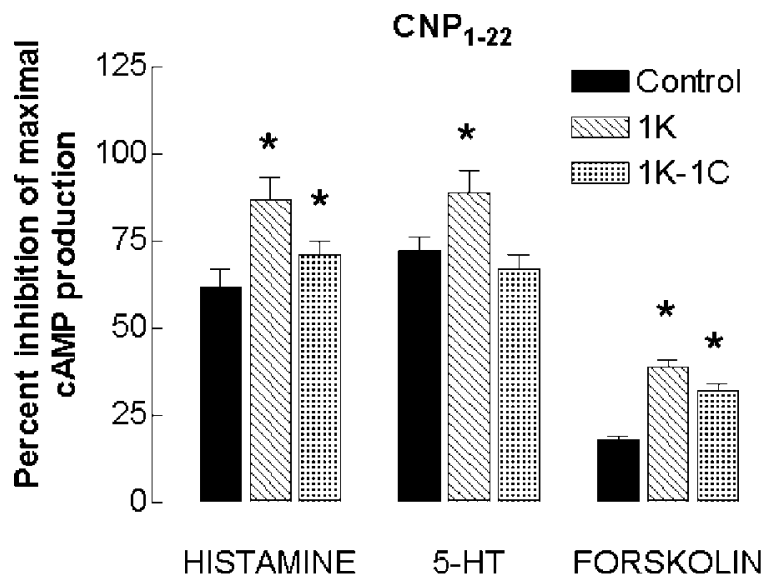

C

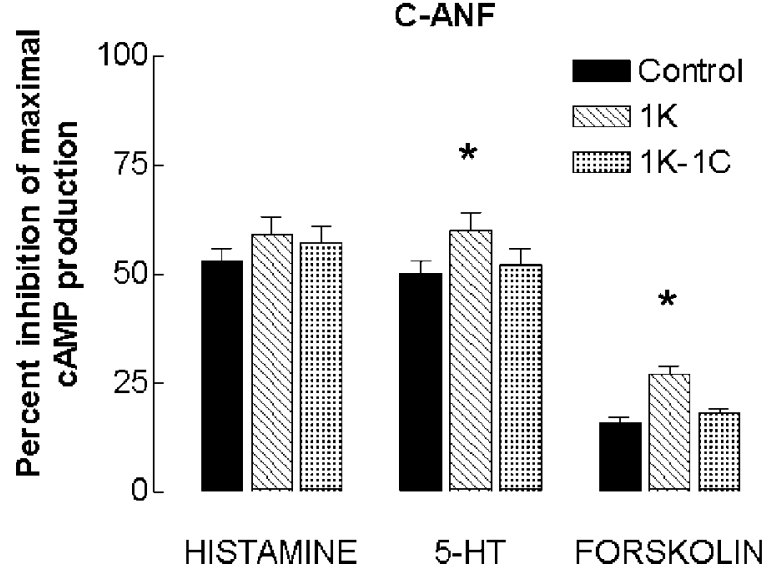

binding site for ANP in 3- and 12-week-old rats (Fig. 5). ${ }^{125} \mathrm{I}_{-\mathrm{ANP}} \mathrm{A}_{1-28}$ and ${ }^{125} \mathrm{I}_{-\mathrm{CNP}} \mathrm{CN}_{1-22}$ bound mostly to glomeruli. Radioligand binding to these structures was virtually abolished in the presence of $1 \mu \mathrm{M}$ unlabelled $\mathrm{ANP}_{1-28}, \mathrm{CNP}_{1-22}$ and $\mathrm{C}-\mathrm{ANF}$ (Fig. 5 ; $n=6$ ).

Competitive inhibition of ${ }^{125} \mathrm{I}_{-} \mathrm{ANP}_{1-28}$ binding by $\mathrm{ANP}_{1-28}$ and $\mathrm{CNP}_{1-22}$ was further examined in 3- and 12 -week-old rats. $\mathrm{ANP}_{1-28}$ displaced ${ }^{125} \mathrm{I}^{1-\mathrm{ANP}_{1-28}}$ in a concentration-dependent manner both in 3- and 12-week-old rats (data not shown). We found that 3-week-old rats have a greater $B_{\max }$ value of the glomerular binding sites for $\mathrm{ANP}_{1-28}$ but a similar affinity for this peptide (Table 3). A similar effect was observed when ${ }^{125} \mathrm{I}-\mathrm{CNP}_{1-22}$ binding was tested. In 3-week-old rats the $\mathrm{B}_{\max }$ value of the glomerular binding sites for $\mathrm{CNP}_{1-22}$ was increased without any detectable affect on its affinity (Table 3). Further competitive inhibition of ${ }^{125}{\mathrm{I}-\mathrm{CNP}_{1-22}}_{1}$ binding to glomeruli by $\mathrm{ANP}_{1-28}$ and $\mathrm{C}-\mathrm{ANF}$ revealed that this class has high affinity for $\mathrm{CNP}_{1-22,} \mathrm{ANP}_{1-28}$ and $\mathrm{C}-\mathrm{ANF}$ (not shown).
Figure 4 Effect of natriuretic peptides on cAMP generation in glomeruli from control, $1 \mathrm{~K}$ and $1 \mathrm{~K} / 1 \mathrm{C}$ rats. Glomeruli from control, $1 \mathrm{~K}$ and $1 \mathrm{~K} / 1 \mathrm{C}$ rats were stimulated with $5 \mu \mathrm{M}$ histamine, $0.1 \mu \mathrm{M}$ 5-hydroxytryptamine $(5-\mathrm{HT})$ or $10 \mu \mathrm{M}$ forskolin in the absence and presence of $\mathrm{ANP}_{1-28}(\mathrm{~A}), \mathrm{CNP}_{1-22}$ (B) or C-ANF (C). cAMP synthesis was measured as described under Materials and methods; values are expressed as percentage inhibition of the response in the absence of natriuretic peptides and are presented as means \pm S.E.M. from six separate experiments. ${ }^{*} P<0.05$ compared with the effect observed in control rats.

These results indicate that the NPR-C-like binding site, which resembles the $67 \mathrm{kDa}$ protein, significantly increases in the developing kidney of 3-week-old rats, while the binding sites related to NPR-A-like or NPR-C-like binding sites resembling the $77 \mathrm{kDa}$ protein remained unaltered.

The competitive inhibition of the binding of ${ }^{125} \mathrm{I}-\mathrm{ANP}_{1-28}$ to glomeruli by $\mathrm{CNP}_{1-22}$ showed two binding sites with different affinities for $\mathrm{CNP}_{1-22}$ in 12and 3-week-old rats. The $\mathrm{pKa}$ and $\mathrm{B}_{\max }$ for these two binding sites are shown in Table 3 and suggest that the binding site with high affinity for $\mathrm{CNP}_{1-22}$ was significantly increased in 3- compared with 12 -week-old rats $(P<0.01)$; in contrast, the binding site with low affinity for $\mathrm{CNP}_{1-22}$ remained unchanged in both 3- and 12-week-old rats $(P>0 \cdot 05)$.

Meanwhile, the competitive inhibition of ${ }^{125} \mathrm{I}-$ $\mathrm{ANP}_{1-28}$ by unlabelled $\mathrm{C}$-ANF on glomeruli of the two groups of rats showed that $1 \mu \mathrm{M}$ C-ANF abolished the binding differences between them (not shown). The 


\section{$\left[^{125} I_{-A N P_{1-28}} \quad\left[^{125} \mid\right]-\mathrm{CNP}_{1-22}\right.$}

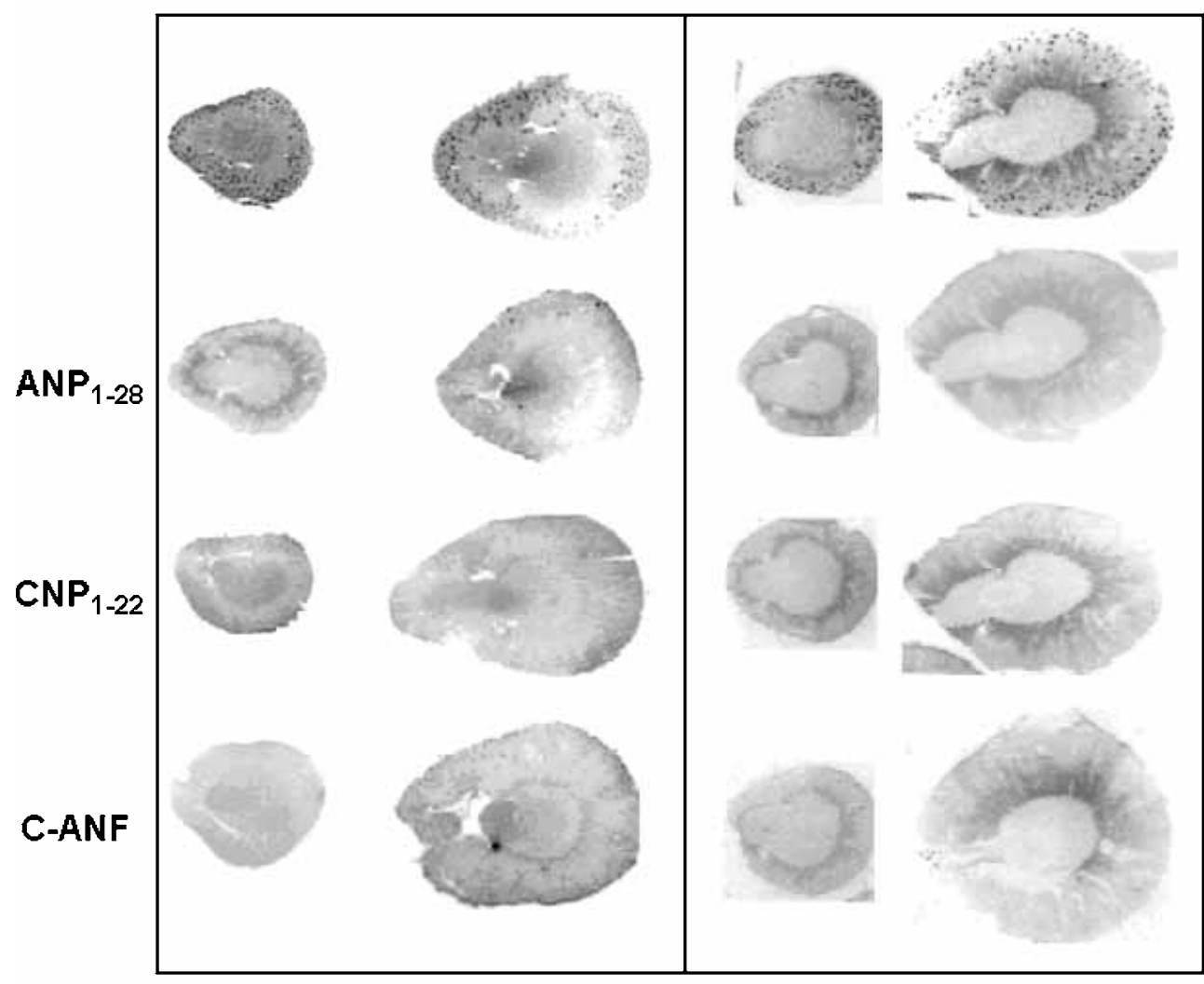

\section{3-week old 12-week old 3-week old 12-week old}

Figure 5 Autoradiographs of renal binding of $100 \mathrm{pM}^{125} \mathrm{I}_{-\mathrm{ANP}_{1-28}}$ or ${ }^{125} \mathrm{I}_{-} \mathrm{CNP}_{1-22}$ in 3- and 12-week-old rats. Sections of kidney from 3- and 12-week-old rats were incubated with $100 \mathrm{pM}{ }^{125} \mathrm{I}_{-\mathrm{ANP}_{1-28}}$ or ${ }^{125} \mathrm{I}_{-} \mathrm{CNP}_{1-22}$ in the absence and presence of $1 \mu \mathrm{M} \mathrm{ANP}_{1-28}, \mathrm{CNP}_{1-22}$ and C-ANF, as indicated, at $20^{\circ} \mathrm{C}$ for $15 \mathrm{~min}$. Autoradiography was performed as described under Materials and methods.

specific glomerular binding of ${ }^{125} \mathrm{I}_{-} \mathrm{ANP}_{1-28}$ in the absence of $\mathrm{C}$-ANF was $467 \pm 73 \mathrm{fmol} / \mathrm{mg}$ protein in 12 -week-old rats and $909 \pm 132 \mathrm{fmol} / \mathrm{mg}$ protein in 3-week-old rats $(P<0 \cdot 01)$, while the corresponding figures with $\mathrm{C}$-ANF were $167 \pm 58 \mathrm{fmol} / \mathrm{mg}$ protein and $164 \pm 71 \mathrm{fmol} / \mathrm{mg}$ protein $(P>0 \cdot 05)$. These results

Table 3 Binding constants for the specifically reversible binding of $\mathrm{ANP}_{1-28}$ or $\mathrm{CNP}_{1-22}$ in the glomeruli of 3- and 12-week old rats. Values are means \pm S.E.M.

\begin{tabular}{|c|c|c|c|c|c|c|}
\hline & \multicolumn{3}{|c|}{ 3-week-old rats } & \multicolumn{3}{|c|}{ 12-week-old rats } \\
\hline & $\mathrm{pKa}$ & $\begin{array}{l}K_{\mathrm{d}} \\
(\mathrm{nM})\end{array}$ & $\begin{array}{l}\mathrm{B}_{\max } \\
\text { (fmol/mg protein) }\end{array}$ & $\mathrm{pKa}$ & $\begin{array}{l}K_{\mathrm{d}} \\
(\mathrm{nM})\end{array}$ & $\begin{array}{l}\mathrm{B}_{\max } \\
\text { (fmol/mg protein }\end{array}$ \\
\hline \multicolumn{7}{|l|}{ Ligand } \\
\hline $\mathrm{HA}+\mathrm{A}$ & $8.48 \pm 0.51$ & $3 \cdot 31$ & $909 \pm 32^{* *}$ & $8 \cdot 46 \pm 0.20$ & 3.40 & $467 \pm 13$ \\
\hline $\mathrm{HA}+\mathrm{C}$ & $8.46 \pm 0.85$ & $2 \cdot 40$ & $769 \pm 14^{\star *}$ & $8.52 \pm 0.33$ & 2.44 & $358 \pm 14$ \\
\hline & $3.42 \pm 1.21$ & 3.93 & $144 \pm 7 \cdot 4$ & $5.62 \pm 0.93$ & 3.48 & $238 \pm 11$ \\
\hline $\mathrm{HC}+\mathrm{C}$ & $8.54 \pm 0.74$ & 2.90 & $534 \pm 36^{\star *}$ & $8 \cdot 44 \pm 1 \cdot 10$ & $3 \cdot 71$ & $263 \pm 27$ \\
\hline
\end{tabular}

The maximum binding capacities $\left(\mathrm{B}_{\max }\right)$ and $\mathrm{pKa}$ were assessed from the competitive inhibition of the binding of

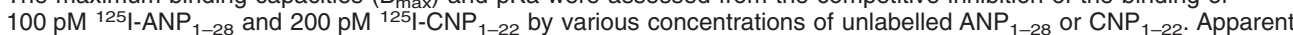
dissociation constants $\left(K_{\mathrm{d}}\right)$ are also given. ${ }^{\star \star} P<0.01$ relative to 12 -week old rats. HA, ${ }^{125}$ I-ANP $_{1-28} ; \mathrm{A}, \mathrm{ANP}_{1-28} ; \mathrm{HC}$, ${ }_{125} \mathrm{I}_{-} \mathrm{CNP}_{1-22} ; \mathrm{C}, \mathrm{CNP}_{1-22}$. In $\mathrm{HA}+\mathrm{C}$ data for high and low affinity binding sites are reported. 
A

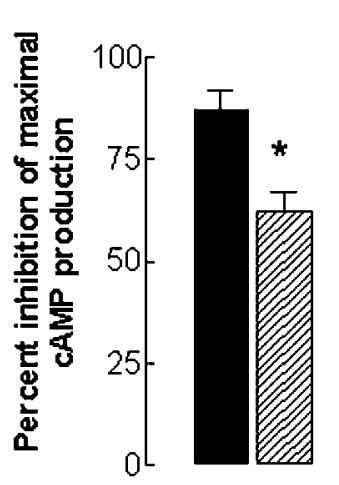

HISTAMINE
$\mathrm{ANP}_{1-28}$

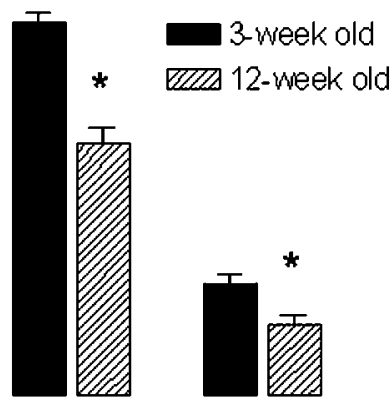

$5-\mathrm{HT}$

FORSKOLIN

\section{C-ANF}

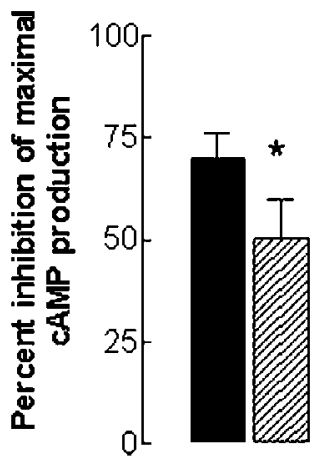

HISTAMINE

B

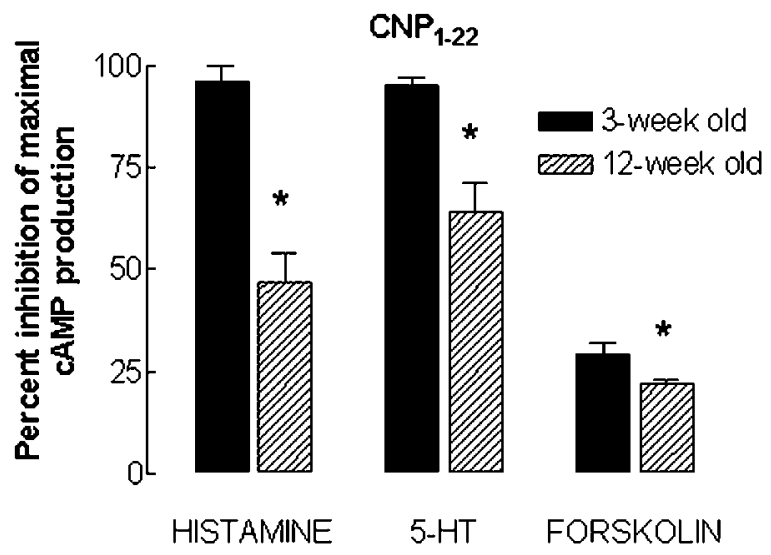

Figure 6 Effect of natriuretic peptides on cAMP generation in glomeruli from 3- and 12-week-old rats. Glomeruli from 3- and 12-week-old rats were stimulated with $5 \mu \mathrm{M}$ histamine, $0.1 \mu \mathrm{M}$ 5-hydroxytryptamine (5-HT) or $10 \mu \mathrm{M}$ forskolin in the absence and presence of $\mathrm{ANP}_{1-28}(\mathrm{~A}), \mathrm{CNP}_{1-22}(\mathrm{~B})$ or C-ANF (C). cAMP synthesis was measured as described under Materials and methods; values are expressed as percentage inhibition of the response in the absence of natriuretic peptides and are presented as means \pm S.E.M. from six separate experiments. ${ }^{*} P<0.05$ compared with the effect observed in control rats.

suggest that NPR-C-like binding sites increase in 3 -week-old rats compared with the 12-week-old rats while the NPR-A binding site remains unchanged.

\section{Effects of $\mathrm{ANP}_{1-28}, \mathrm{CNP}_{1-22}$ or C-ANF on cAMP stimulated by histamine, 5-HT or forskolin in 3- and 12-week-old rats}

The basal rate of glomerular cAMP accumulation in the presence of IBMX was $3 \cdot 1 \pm 0 \cdot 2$ and $3 \cdot 0 \pm 0 \cdot 2 \mathrm{fmol} / \mathrm{mg}$ protein in 3- and 12-week-old rats. Histamine $(5 \mu \mathrm{M})$, 5-HT $(0 \cdot 1 \mu \mathrm{M})$ and forskolin $(10 \mu \mathrm{M})$ increased cAMP content in both groups of rats. As shown in Fig. 6, treatment with $1 \mu \mathrm{M} \mathrm{ANP}_{1-28}, \mathrm{CNP}_{1-22}$ or $\mathrm{C}$-ANF reduced cAMP production by these agents significantly $(P<0 \cdot 05 ; n=6)$. However, the inhibitory effect of the natriuretic peptides was significantly higher in 3-week-old rats compared with 12-week-old rats (Fig. 6; $P<0 \cdot 05$ ).

\section{Discussion}

Our results indicate that kidney hypertrophy increases the expression of the $67 \mathrm{kDa}$ NPR-C-like protein in renal glomeruli. As a result, $\mathrm{ANP}_{1-28}, \mathrm{CNP}_{1-22}$ and C-ANF show a greater inhibitory effect on cAMP production stimulated by the agonists histamine, 5-HT or forskolin in glomeruli from hypertrophied kidney rats as compared with those from controls.

The autoradiographic study agrees with previous results reporting that rat renal glomeruli express two types of NPR-G-like receptors (Woodard et al. 2004a). The competitive inhibition of ${ }^{125} \mathrm{I}_{-} \mathrm{ANP}_{1-28}$ binding to the glomeruli by $\mathrm{CNP}_{1-22}$ showed that there were two binding sites with different affinities for $\mathrm{CNP}_{1-22}$, one with high affinity, supposedly the $67 \mathrm{kDa}$ NPR-C-like protein, and the other with low affinity, the $77 \mathrm{kDa}$ NPR-G-like receptor.

Our results indicate that expression of NPR-C-like binding sites was increased in $1 \mathrm{~K}$ and $1 \mathrm{~K} / 1 \mathrm{C}$ rats as 
well as in 3-week-old rats, but that NPR-A and NPR-B remained unaltered. We further showed that the NPR-G-like protein with high affinity for $\mathrm{CNP}_{1-22}$, described as the $67 \mathrm{kDa}$ NPR-C-like binding site (Anand-Srivastava \& Trachte 1993), rather than that with low affinity, identified as the $77 \mathrm{kDa}$ NPR-G-like protein (Anand-Srivastava \& Trachte 1993), is the binding site that is increased in the experimental groups mentioned above. Although the different $\mathrm{B}_{\max }$ values in NPR-C between $1 \mathrm{~K}, 1 \mathrm{~K} / 1 \mathrm{C}$ and control rats, as well as between 3- and 12-week-old rats, may be attributed to the differences in radioligand breakdown during incubation with renal sections, HPLC studies have reported that a similar amount of ${ }^{125}{\mathrm{I}-\mathrm{ANP}_{1-28}}_{\text {was }}$ recovered after incubation with renal sections from $1 \mathrm{~K}$, $1 \mathrm{~K} / 1 \mathrm{C}$ and control rats, as well as from 3- and 12-week-old rats, suggesting that the effective concentrations of radioligand were similar for the different experimental groups. In addition, the renal sections were preincubated and washed in $150 \mathrm{mM}$ sodium chloride plus $0.5 \%$ acetic acid $(\mathrm{pH} 5 \cdot 0)$ at $4{ }^{\circ} \mathrm{C}$ for $10 \mathrm{~min}$ to completely remove the endogenous bound ligands (Gunning et al. 1988, Martin \& Lewicki 1989). Therefore, the differences in the $\mathrm{B}_{\max }$ values among the different groups of rats could not be attributed to the differences in endogenous bound ligands.

cAMP production stimulated by the agonists histamine, 5-HT or forskolin were examined in the presence of IBMX, an inhibitor of phosphodiesterases that inhibits the cGMP-activated phosphodiesterase that may account for the effects of natriuretic peptides on cAMP levels (Beavo \& Reifsnyder 1990). Therefore, our findings suggest that natriuretic peptides induce a greater reduction of cAMP levels in glomeruli from $1 \mathrm{~K}$ and $1 \mathrm{~K} / 1 \mathrm{C}$ rats by decreasing the rate of cAMP synthesis more effectively in these groups. In addition, our results indicate that natriuretic peptides induce a greater inhibition of cAMP production stimulated by physiological agonists, such as histamine or 5-hydroxytryptamine, in developing 3-week-old rats than in 12-week-old rats, which further suggests the physiological significance of natriuretic peptides.

The $67 \mathrm{kDa}$ NPR-C-like protein with high affinity for $\mathrm{CNP}_{1-22}$ has been reported to inhibit cAMP synthesis (Brown \& Zuo 1994, Woodard et al. 2004a). The increase in the $B_{\max }$ value for the high affinity binding site of NPR-C in both the hypertrophied and developing kidney groups of rats together with the increase in the ability to inhibit cAMP generation confirms the view that the enhanced NPR-C-like binding site is the $67 \mathrm{kDa}$ NPR-G-like protein and may be involved in the regulation of cAMP levels.

There is still some controversy at present about the mechanism by which natriuretic peptides inhibit cAMP production after binding to the $67 \mathrm{kDa}$ NPR-C-like receptor. $\mathrm{ANP}_{1-28}$ is known to decrease cAMP levels in some tissues by stimulating the synthesis of cGMP, which, in turn, activates a cGMP-dependent phosphodiesterase of cAMP (McFarland et al. 1991). On the other hand, a number of studies have suggested that $\mathrm{CNP}_{1-22}, \mathrm{BNP}$ and $\mathrm{C}-\mathrm{ANF}$ interact with NPR-C receptors resulting in the inhibition of adenylyl cyclase activity probably by the activation of a pertussis-sensitive Gi protein (Anand-Srivastava 1997, Rose et al. 2003, Callahan et al. 2004, Woodard et al. 2004a). Our results did not support the concept that natriuretic peptides decrease cAMP via a cGMP-dependent phosphodiesterase since $\mathrm{CNP}_{1-22}$-induced inhibition of cAMP production was detected at a concentration of $1 \mathrm{nM}$ which is 100 -fold lower than the minimum dose required to stimulate cGMP production in rat glomeruli (data not shown). Moreover, the actions of natriuretic peptides on cAMP production were investigated in the presence of $1 \mathrm{mM}$ IBMX in our conditions. These findings indicate that natriuretic peptides reduced cAMP synthesis by inhibiting the rate of cAMP generation rather than by activating a cGMP-dependent phosphodiesterase specific for cAMP.

The fact that the expression of $67 \mathrm{kDa}$ NPR-G-like protein significantly increases in $1 \mathrm{~K}$ and $1 \mathrm{~K} / 1 \mathrm{C}$ rats as well as in 3-week-old rats suggests that this receptor may be involved in growth regulation, since the kidney in both $1 \mathrm{~K}$ and $1 \mathrm{~K} / 1 \mathrm{C}$ rats shows significant hypertrophy and that of 3-week-old rats is in a developing state. Recent evidence supports the view that natriuretic peptides have growth-regulatory properties; however, the cellular mechanisms involved in this role are not well established, although NPR-C may be involved in this function (Cahill \& Hassid 1991, Lelievre et al. 2001). A recent study reports that epidermal growth factor reduces the expression of NPR-C by a mechanism involving activator protein-1, which suggests that NPR-G might mediate the growth-regulatory actions of ANP (Placier et al. 2001). Therefore, it has been suggested that NPR-C is involved in the regulation of cell growth; however, it remains to be elucidated which type of NPR-C-like protein is involved in this function. The increase in expression of the $67 \mathrm{kDa}$ NPR-C-like protein in rats with developing and hypertrophied kidneys suggests that this receptor might be involved in the regulation of tissue growth. Although speculative, the $67 \mathrm{kDa}$ NPR-C-like receptor may be involved in the regulation of growth through the inhibition of cAMP synthesis as there is a body of evidence supporting a role for cyclic nucleotides in cell proliferation in a variety of tissues (Dremier et al. 2002, Dormond \& Ruegg 2003), including kidney (Yamaguchi et al. 2000, Ito et al. 2004).

Although several studies reported that both NPR-A and NPR-C are down regulated in $1 \mathrm{~K} / 1 \mathrm{C}$ rats compared with normotensive $1 \mathrm{~K}$ rats as a result of hypertension, we have not found significant differences in the expression of NPR-C between $1 \mathrm{~K}$ and $1 \mathrm{~K} / 1 \mathrm{C}$ 
rats under our experimental conditions. One reason for this discrepancy might be the different rat strain used, WKY rats in our study and Sprague-Dawley rats in others (Bonhomme \& García 1993). Alternatively, we have found that the amount of kidney hypertrophy in $1 \mathrm{~K}$ and $1 \mathrm{~K} / 1 \mathrm{C}$ rats is similar under our conditions, while in other studies, the kidneys in $1 \mathrm{~K} / 1 \mathrm{C}$ rats showed significantly less hypertrophy than those in $1 \mathrm{~K}$ rats (García et al. 1988).

In summary, our observations demonstrate that two types of NPR-C-like proteins that resemble the $67 \mathrm{kDa}$ and $77 \mathrm{kDa}$ proteins are independently regulated receptors. Expression of the receptor resembling the $67 \mathrm{kDa}$ protein is significantly increased in renal glomeruli under hypertrophy and growth situations. In addition, natriuretic peptides have an enhanced inhibitory effect on cAMP synthesis in hypertrophied and developing kidney, which may influence glomerular function, suggesting a role for the $67 \mathrm{kDa}$ NPR-C-like protein in the physiological regulation of tissue growth through the modulation of cAMP synthesis.

\section{Acknowledgements}

The British Heart Foundation supported this work. The authors declare that there is no conflict of interest that would prejudice the impartiality of this scientific work.

\section{References}

Anand-Srivastava MB 1997 Atrial natriuretic peptide-C receptor and membrane signalling in hypertension. Fournal of Hypertension $\mathbf{1 5}$ 815-826.

Anand-Srivastava MB \& Trachte GJ 1993 Atrial natriuretic factor receptors and signal transduction mechanisms. Pharmacological Reviewes 45 455-497.

Appel RG 1990 Mechanism of atrial natriuretic factor-induced inhibition of rat mesangial cell mitogenesis. American Fournal of Physiology 259 312-318.

Appel RG 1992 Growth-regulatory properties of atrial natriuretic factor. American Fournal of Physiology 262 911-918.

Beavo JA \& Reifsnyder DH 1990 Primary sequence of cyclic nucleotide phosphodiesterase isozymes and the design of selective inhibitors. Trends in Pharmacological Sciences 11 150-155.

Bonhomme MC \& García R 1993 Heterogeneous regulation of renal atrial natriuretic factor receptor subtypes in one kidney/one clip hypertensive rats. Fournal of Hypertension 11 389-397.

Brown J \& Chen Q 1995 Regional expression of natriuretic peptide receptors during the formation of arterial neointima in the rabbit. Circulation Research 77 906-918.

Brown J \& Zuo Z 1992 Renal receptors for atrial and C-type natriuretic peptides in the rat. American Fournal of Physiology 263 89-96.

Brown J \& Zuo Z 1994 Receptor proteins and biological effects of C-type natriuretic peptides in the renal glomerulus of the rat. American Foumal of Physiology 266 1383-1394.

Cahill PA \& Hassid A 1991 Clearance receptor-binding atrial natriuretic peptides inhibit mitogenesis and proliferation of rat aortic smooth muscle cells. Biochemical and Biophysical Research Communication 179 1606-1613.
Cahill PA \& Hassid A 1994 ANF-C-receptor-mediated inhibition of aortic smooth muscle cell proliferation and thymidine kinase activity. American Fournal of Physiology 266 194-203.

Chen HH \& Burnett JC Jr 1998 C-type natriuretic peptide: the endothelial component of the natriuretic peptide system. Fournal of Cardiovascular Pharmacology 3 22-28.

Dhingra H, Roongsritong C \& Kurtzman NA 2002 Brain natriuretic peptide: role in cardiovascular and volume homeostasis. Seminars in Nephrology 22 423-437.

Dormond O \& Ruegg C 2003 Regulation of endothelial cell integrin function and angiogenesis by COX-2, cAMP and protein kinase A. Thrombosis and Haemostasis 90 577-585.

Dremier S, Coulonval K, Perpete S, Vandeput F, Fortemaison N, Van Keymeulen A, Deleu S, Ledent C, Clement S, Schurmans S, Dumont JE, Lamy F, Roger PP \& Maenhaut C 2002 The role of cyclic AMP and its effect on protein kinase $\mathrm{A}$ in the mitogenic action of thyrotropin on the thyroid cell. Annals of the New York Academy of Sciences 968 106-121.

Fan D, Bryan PM, Antos LK, Potthast RJ \& Potter LP 2005 Down-regulation does not mediate natriuretic peptide-dependent desensitization of natriuretic peptide receptor (NPR)-A or NPR-B: guanylyl cyclase-linked natriuretic peptide receptors do not internalize. Molecular Pharmacology 67 174-183.

García R, Gauquelin G, Cantin M \& Schiffrin EL 1988 Renal glomerular atrial natriuretic factor receptors in one-kidney, one-clip rats. Hypertension 11 185-190.

Gunning ME, Ballermann BJ, Silva P, Brenner BM \& Zeidel ML 1988 Characterization of ANP receptors in rabbit inner medullary collecting duct cells. American fournal of Physiology 255 324-330.

Ito C, Yamamoto H, Furukawa Y, Takeda S, Akimoto T, Iimura O, Ando Y, Asano Y \& Kusano E 2004 Role of cyclins in cAMP inhibition of glomerular mesangial cell proliferation. Clinical Science 107 81-87.

Johnson GR \& Foster CJ 1990 Partial characterization of a metalloendopeptidase activity produced by cultured endothelial cells that removes the $\mathrm{COOH}$-terminal tripeptide from ${ }^{125} \mathrm{I}$-atrial natriuretic factor. Biochemical and Biophysical Research Communications $167110-116$.

Koller KJ, Lowe DG, Bennett GL, Minamino N, Kangawa K, Matsuo H \& Goeddel DV 1991 Selective activation of the B natriuretic peptide receptor by $\mathrm{C}$-type natriuretic peptide (CNP). Science 252 120-123.

Lelievre V, Pineau N, Hu Z, Ioffe Y, Byun JY, Muller JM \& Waschek JA 2001 Proliferative actions of natriuretic peptides on neuroblastoma cells. Involvement of guanylyl cyclase and non-guanylyl cyclase pathways. Fournal of Biological Chemistry 276 43668-43676.

Lu SY, Zhu MZ, Wang DS, Chen SY, Zhang WD, Dong H, Yu J \& Guo HT 2004 Inhibition of the proliferation of smooth muscle cells from human coronary bypass vessels by vasonatrin peptide. Physiological Research 53 387-393.

MacFarland RT, Zelus BD \& Beavo JA 1991 High concentrations of a cGMP-stimulated phosphodiesterase mediate ANP-induced decreases in cAMP and steroidogenesis in adrenal glomerulosa cells. Fournal of Biological Chemistry 266 136-142.

Martin ER \& Lewicki JA 1989 Expression and regulation of ANP receptor subtypes in rat renal glomeruli and papillae. American Journal of Physiology 257 649-657.

Matsuo H 2001 Discovery of a natriuretic peptide family and their clinical application. Canadian Fournal of Physiology and Pharmacology 79 736-740.

Murakami S, Nagaya N, Itoh T, Fujii T, Iwase T, Hamada K, Kimura H \& Kangawa K 2004 C-type natriuretic peptide attenuates bleomycin-induced pulmonary fibrosis in mice. American fournal of Physiology. Lung Cellular and Molecular Physiology 287 1172-1177.

Nakao K, Ogawa Y, Suga S \& Imura H 1992 Molecular biology and biochemistry of the natriuretic peptide system. II. Natriuretic peptide receptors. Fournal of Hypertension 10 1111-1115. 
Placier S, Bretot X, Ardaillou N, Dussaule JC \& Ardaillou R 2001 Regulation of ANP clearance receptors by EGF in mesangial cells from NOD mice. American Fournal of Physiology. Renal Physiology 281 244-254.

Prins BA, Weber MJ, Hu RM, Pedram A, Daniels M \& Levin ER 1996 Atrial natriuretic peptide inhibits mitogen-activated protein kinase through the clearance receptor. Potential role in the inhibition of astrocyte proliferation. Fournal of Biological Chemistry 271 14156-14162.

Rademaker MT \& Richards AM 2005 Cardiac natriuretic peptides for cardiac health. Clinical Science 108 23-36.

Rose RA, Lomax AE \& Giles WR 2003 Inhibition of L-type $\mathrm{Ca}^{2+}$ current by C-type natriuretic peptide in bullfrog atrial myocytes: an NPR-C-mediated effect. American Fournal of Physiology. Heart and Circulatory Physiology 285 2454-2462.

Scotland RS, Ahluwalia A \& Hobbs AJ 2005 C-type natriuretic peptide in vascular physiology and disease. Pharmacology and Therapeutics 105 85-93.

Woodard GE, Rosado JA \& Brown J 2002 Dendroaspis natriuretic peptide-like immunoreactivity and its regulation in rat aortic vascular smooth muscle. Peptides 23 23-29.
Woodard GE, Li X \& Rosado JA 2004a Water deprivation enhances the inhibitory effect of natriuretic peptides on cAMP synthesis in rat renal glomeruli. American Fournal of Physiology. Renal Physiology $287418-426$.

Woodard GE, Zhao J, Rosado JA \& Brown J 2004b Patterning of renal cGMP production by the natriuretic peptide receptor type A and blood pressure in spontaneously hypertensive rats. Regulatory Peptides 119 45-51.

Woodard GE, Li X \& Rosado JA 2005 Receptor subtypes for vasonatrin peptide in renal glomeruli and arteries. Regulatory Peptides (In Press).

Yamaguchi T, Pelling JC, Ramaswamy NT, Eppler JW, Wallace DP, Nagao S, Rome LA, Sullivan LP \& Grantham JJ 2000 cAMP stimulates the in vitro proliferation of renal cyst epithelial cells by activating the extracellular signal-regulated kinase pathway. Kidney International 57 1460-1471.

Received 21 September 2005

Accepted 30 September 2005

Made available online as an Accepted Preprint 5 October 2005 